\title{
The Influence of Organizational Commitment to the Relationship of Leadership Style and Performance
}

\author{
Dwi Sudaryati ${ }^{1 *}$, Sucahyo Heriningsih ${ }^{2}$, Lita Yulita Fitriyani ${ }^{3}$ \\ ${ }^{1}$ Faculty of Economics and Business, UPN "Veteran” Yogyakarta \\ ${ }^{2}$ Faculty of Economics and Business, UPN "Veteran” Yogyakarta \\ ${ }^{3}$ Faculty of Economics and Business, UPN “Veteran” Yogyakarta \\ "Corresponding author. Email: dwi.sudaryati@upnyk.ac.id
}

\begin{abstract}
This study aims to determine the effect of organizational commitment to the relationship between leadership style and BUMDes employee performance. This research was conducted at BUMDes in Bantul Regency using survey methods. The population and sample in this study were employees of BUMDes in Bantul Regency with 105 respondents. The analysis technique used in this study is Partial Least Square (PLS). The results showed that the leadership style had a direct influence on the performance of BUMDes employees. The results also show that organizational commitment cannot mediate the relationship between leadership style and BUMDesa employee performance. These results have implications for BUMDes to be able to apply the right leadership style and pay more attention to employees in order to improve performance in the context of managing BUMDesa.
\end{abstract}

Keywords: BUMDesa, Leadership Style, Organizational Commitment, Performance.

\section{INTRODUCTION}

The village is the smallest unit of the State that is directly related to the welfare needs of the community. The Government through the Village Law seeks to realize village independence through its authority to manage resources and develop the potential of the village. The development of economic potential must be carried out to increase village development in order to create village welfare and independence. BUMDesa is a business entity formed by the village government with the aim to explore and develop the potential that exists in the village. BUMDesa management is separate from the village government and managed by the village community.

The success of BUMDesa is greatly influenced by the performance of individual employees. Performance is the result of individual responses related to their abilities and attitudes towards work and organization. Every organization always strives to improve employee performance in order to achieve goals. BUMDesa employee performance has an important role for BUMDesa. If employees carry out their duties properly and correctly, it will have a positive effect on BUMDesa's performance.

In order for BUMDesa to achieve its stated mission, vision and goals, a leader is needed. BUMDesa leaders are expected to be able to bring BUMDesa to progress, develop and be competitive. The quality of a leader is a determining factor for organizational success or failure. A leader has a way to influence other people or subordinates so that people want to act in accordance with the wishes of the leadership to achieve organizational goals, called leadership style (Luthans, 2002). Leadership style will make subordinates have a sense of belonging to the job and organization. The leader is certainly able to instill work discipline for employees to improve performance, and be able to influence employee creativity in completing their tasks. (Baig et al., 2019) shows that employee performance includes assigned tasks, employee competencies, and effectiveness and efficiency in doing work. Various organizations need strong leadership styles that stimulate employee performance. Of course, a strong leadership style is needed at BUMDesa for optimal effectiveness.

Employees with high commitment are expected to be able to produce optimal performance. When someone joins an organization, they are required to have a commitment in themselves. Low commitment raises problems for the organization, because commitment is an expensive "commodity" that determines the success of the organization. Low commitment reflects a person's lack of responsibility in carrying out their duties. (Yousef, 2000; Lok and Crawford, 2004; Jaramillo, Mulki and Marshall, 2005) found that organizational commitment mediates the relationship between leadership behavior and performance, where organizational members are more satisfied with their 
work and their performance is high.

Research on performance in BUMDesa has not been done much. This study uses organizational commitment as an intervening variable because employees who enforce commitment to their organization, will not be easily influenced and will not be influenced by sharing things that come from outside themselves in carrying out their work duties. Thus, a BUMDesa employee will get better performance if supported by a leadership style and has a high commitment to the organization. This study aims to prove empirically whether organizational commitment as a variable intervening will mediate the influence of leadership style on the performance of BUMDesa employees.

\section{HYPOTHESIS DEVELOPMENT}

\subsection{Relationship between Leadership Style and Performance}

Leaders not only influence the utilization of resources owned by the organization in accordance with policies, right but the leader has the power to force other resources (Trisnaningsih, 2007). Leadership style is a way for leaders to influence other people or other subordinates so that the person wants to do the will of the leader to achieve the goals of the organization even though personally it might not be liked (Luthans, 2002). There are several important situational factors that influence leadership style, including the quality of the relationship between leaders and subordinates, the structure of the tasks undertaken and the strength of the leader's position (Mardiana, 2003 and Wijaya 2006).

Good leaders motivate employees and motivated employees not only improve performance in an organization, but also go beyond job requirements thereby increasing the general performance of the organization and making it more profitable (Nawoseing'ollan and Roussel, 2017). Goleman (2004) states that manager's leadership style affects employee performance. However, the results of the study (Irene Muhoho \& Dr.Oloko Margret, 2016) confirmed that improper leadership styles can directly affect the performance of organizational employees. Therefore, not all leadership styles have the same influence on the achievement of company goals, the use of inappropriate leadership styles will actually reduce employee performance. An effective leader has the responsibility to provide guidance and share knowledge with employees to lead them to better performance and make them experts to maintain quality (Baig et al., 2019). The right leadership style will be able to improve employee performance, which in turn will also improve overall organizational performance.

Based on the explanation above, the research hypothesis is formulated as follows:

H1: Leadership style influences performance

\subsection{Relationship of Leadership Style to Organizational Commitment}

Leadership is the key to good performance because it coordinates the utilization of human resources and other resources in the organization, good leaders motivate employees and motivated employees will increase their work commitment in an organization so as to improve organizational performance (Nawoseing'ollan and Roussel, 2017). Leadership style refers to the behavior and attitudes of leaders in governance and supervision. This is the result of personality traits, experiences, attitudes and philosophies of leaders (Baig et al., 2019).

Organizational commitment is the willingness of social actors to give their efforts and loyalty to the social system. Attachment to the personality system of social relations can be in the form of self-expression, so as to improve employee morale and behavior to work better and produce their work performance (Lapointe and Vandenberghe, 2018). revealed that leadership style variables are able to influence job satisfaction. Job satisfaction will increase if the leadership style is strengthened. Increased job satisfaction will increase organizational commitment. (Suharto, Suyanto and Hendri, 2019).

Based on the explanation above, the research hypothesis is:

H2: Leadership style influences organizational commitment

\subsection{Relationship of Organizational Commitment to Performance}

Work performance is the stage of achievement as work performance by individuals from the organization. Work performance in an organization is strongly influenced by three main factors: organizational support, ability or effectiveness of management and the performance of each individual working in the organization, where each unit in an organization has several divisions where there are individuals in each division (Nirushan, 2017).

Commitment is a consistency of a person's attachment to something, such as: career, family, social environment and so on. The existence of a commitment can be an impetus for someone to work better or even otherwise cause someone to just leave his job, due to a demand for other commitments (Trisnaningsih, 2007).

Organizational commitment has a significant impact on work performance. Employees with high organizational commitment will show positive behavior to the organization, give the best that they can, sacrifice, and have a high level of loyalty to the organization, and also have a willingness to remain in the organization (Eliyana, Ma'arif and Muzakki, 2019) . Based on the explanation above, the research hypothesis is:

\section{H3: Organizational commitment influences performance}




\subsection{Effects of Organizational Commitment on Relationship between leadership style and performance}

Employees who are committed to their organization will show positive attitudes and behaviors towards their organization. Leadership style of a leader who is supported by a sense of commitment to the organization, it will greatly affect their performance (Trisnaningsih, 2007). In contrast (Yiing and Ahmad, 2009) that leadership style is significantly related to organizational commitment but not to employee performance. The results of the study (Yousef, 2000) show that employees perceive superiors as adopting consultative or participative leadership behaviors more committed to their organizations, more satisfied with their work, and their performance is high.

A person can become a member of an organization to achieve certain personal goals, the extent to which they are active members depends on how confident they are that their membership will enable them to achieve predetermined goals (Obiwuru, et al., 2011). Therefore, a person will support the organization if he believes that through that, his personal goals and objectives can be met; if not, the person's interest will decrease. Leadership style in an organization plays an important role in increasing or slowing the interest and commitment of individuals in the organization which will ultimately improve individual performance.

Based on the results of previous studies mentioned above, the research hypothesis is formulated as follows:

H4: Leadership style indirectly influences performance through organizational commitment.

\section{METHODS, DATA AND ANALYSIS}

This study uses a quantitative approach. This research was conducted at BUMDesa in Bantul Regency. Respondents in this study are BUMDesa operational implementers who are parties directly involved in BUMDesa management. The sampling method in this study uses convenience sampling method and as many as 105 respondents selected samples. Data is collected by using a survey method through a questionnaire.

The variables used in this study consisted of the dependent variable namely performance, the independent variable was leadership style. The moderating variable is organizational commitment. In this study all measurement variables using a 1-5 Likert Scale that allows researchers to dig up appropriate information from respondents about the situation they have experienced.

The analytical method used is Partial Least Square (PLS) using WarpPLS 6.0 software. In general, Partial Least Square (PLS) is very suitable for predicting applications and building theories, analyzing small samples, and testing overall model fit (overall model fit) well (Gefen et al., 2000).

\section{RESULTS AND DISCUSSION}

\subsection{Model Feasibility Test Results}

Table 1. General SEM Analysis Result

\begin{tabular}{lll}
\hline & Value & Ideal \\
\hline $\begin{array}{l}\text { Average Path Coeffecient } \\
\text { (APC) }\end{array}$ & 0,$481 ;$ & $<=0,05$ \\
Average R-Square (ARS) & 0,$497 ;$ & $<=0,05$ \\
& $\mathrm{P}<0,001$ & \\
$\begin{array}{l}\text { Average Variant Inflantion } \\
\text { Factor (AVIF) }\end{array}$ & 2,179 & $<=3,3$ \\
\hline
\end{tabular}

Table 1 above shows the output of the APC value of 0.481 with a p-value $<0.05$ and an ARS value of 0.497 with a p-value of $<0.05$. Likewise, the AVIF value of $2,179(<5)$ which means that there is no multicollinearity problem between exogenous variables. These results indicate that the APC, ARS and AVIF values have met the ideal criteria which means that overall the research model is good (appropriate).

\subsection{Reliability Test Results}

Reliability testing is carried out with the aim to ensure the research instruments used can provide consistent measurement of concepts without bias. The results of WarpPLS 6.0 data processing are as follows:

Table 2. Latent Variable Coefficients

\begin{tabular}{ll|ll}
\hline $\begin{array}{l}\text { Composite } \\
\text { coefficients }\end{array}$ & reliability & $\begin{array}{l}\text { Cronbach's } \\
\text { coefficients }\end{array}$ & alpha \\
\hline Performance & 0,892 & Performance & 0,864 \\
$\begin{array}{l}\text { Leadership } \\
\text { Style }\end{array}$ & 0,909 & Leadership Style & 0,865 \\
$\begin{array}{l}\text { Organizational } \\
\text { Commitment }\end{array}$ & 0,895 & $\begin{array}{l}\text { Organizational } \\
\text { Commitment }\end{array}$ & 0,839 \\
\hline
\end{tabular}

The basis used in the reliability test is the value of Composite reliability coefficients and Cronbach's alpha coefficients above 0.6 . The results in table 2 show that the questionnaire instrument in this study had fulfilled the reliability test requirements.

\subsection{Validity Test Results}

The validation test criteria is to use the cross-loadings factor with a value of more than 0.50 and the average variance extracted (AVE) with a value exceeding 0.50 for the convergent validity test and for the discriminant validity test using the root comparison of AVE with correlation between variables. The construct construct AVE value should be higher than the correlation between latent variables (Solihin and Ratmono, 2013). Based on the results in table 4 shows that the cross-loadings factor value for each 
indicator variable has reached a value above 0.5 with a $\mathrm{p}$ value below 0.001 . Thus the validity test criteria have been met.

Table 4. Combined loadings and cross-loadings factor

\begin{tabular}{|c|l|l|l|l|c|c|}
\hline & KINERIA & GY_KEPM & KOM_ORG & Type (as defined) & SE & P value \\
\hline KN_1 & $(0.671)$ & -0.330 & 0.155 & Reflective & 0.082 & $<0.001$ \\
\hline KN_2 & $(0.795)$ & -0.255 & 0.051 & Reflective & 0.079 & $<0.001$ \\
\hline KN_3 & $(0.776)$ & -0.125 & -0.168 & Reflective & 0.079 & $<0.001$ \\
\hline KN_4 & $(0.511)$ & -0.799 & 0.739 & Reflective & 0.085 & $<0.001$ \\
\hline KN_5 & $(0.707)$ & -0.263 & 0.092 & Reflective & 0.081 & $<0.001$ \\
\hline KN_6 & $(0.659)$ & 0.425 & -0.005 & Reflective & 0.082 & $<0.001$ \\
\hline KN_7 & $(0.536)$ & 0.284 & 0.461 & Reflective & 0.085 & $<0.001$ \\
\hline KN_8 & $(0.585)$ & 0.013 & 0.160 & Reflective & 0.084 & $<0.001$ \\
\hline KN_9 & $(0.796)$ & 0.490 & -0.575 & Reflective & 0.079 & $<0.001$ \\
\hline KN_10 & $(0.655)$ & 0.436 & -0.514 & Reflective & 0.082 & $<0.001$ \\
\hline GK_1 & 0.034 & $(0.837)$ & 0.094 & Reflective & 0.078 & $<0.001$ \\
\hline GK_2 & -0.154 & $(0.914)$ & 0.170 & Reflective & 0.077 & $<0.001$ \\
\hline GK_3 & -0.090 & $(0.864)$ & -0.042 & Reflective & 0.078 & $<0.001$ \\
\hline GK_4 & 0.251 & $(0.759)$ & -0.262 & Reflective & 0.080 & $<0.001$ \\
\hline KO_1 & 0.029 & 0.646 & $(0.675)$ & Reflective & 0.082 & $<0.001$ \\
\hline KO_2 & 0.078 & -0.254 & $(0.910)$ & Reflective & 0.077 & $<0.001$ \\
\hline KO_3 & -0.131 & -0.056 & $(0.920)$ & Reflective & 0.076 & $<0.001$ \\
\hline KO_4 & 0.039 & -0.197 & $(0.775)$ & Reflective & 0.079 & $<0.001$ \\
\hline & & & & & & \\
\hline
\end{tabular}

\subsection{Hypothesis Test Results}

The hypothesis will be accepted if the value of $p<0.05$. The calculation results for WarpPLS 6.0 are as follows:

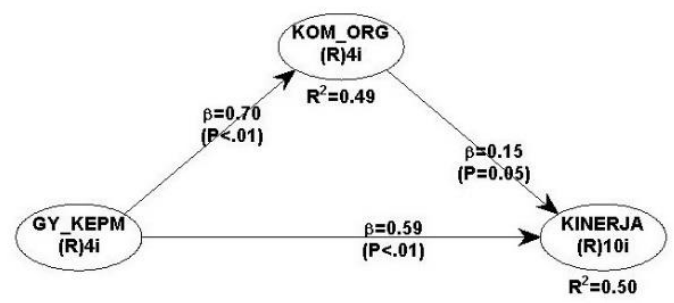

Figure 1. Mediation Test

Source: data processed (2020)

Based on the results of the study in figure 1 it can be seen that $\mathrm{H} 1, \mathrm{H} 2$ are supported. Leadership style influences the performance of BUMDesa operational implementers with the resulting $\mathrm{p}$-value $<0.01$ and the path coefficient value of 0.59 . Next leadership style affects the commitment of performance with $\mathrm{p}$-value $<0.01$ and path coefficient of 0.70 . However, organizational commitment has no effect on performance with a $\mathrm{p}$-value $=0.05$ and a path coefficient of 0.15. Thus, $\mathrm{H} 3$ and $\mathrm{H} 4$ are not supported that organizational commitment cannot be a mediator of the relationship between leadership style and performance.

This shows that when the leadership style is able to create a good and effective atmosphere, employees will feel happy with the leader so that they can improve employee performance. Leadership style will also affect employee commitment to the organization, so employees will be loyal to their work and do not want to move from the job. High commitment will have a real sense of work and positive feelings towards the organization. Authoritative leaders make employees feel proud because they are associated with them because they show a sense of power, make personal sacrifice and always think for the improvement of the whole group. Leaders like this always think about the goals of the organization and talk passionately about them. They also stimulate employees intellectually, re-examine ways of doing things and treat everyone as an individual rather than a group and show empathy when needed and hence affect employee performance (Nawoseing'ollan and Roussel, 2017).

An organization including BUMDesa really needs a leader who is able to bring BUMDesa to maintain consistency and competition. Thus, the role of leadership style in BUMDesa is important in the form of achieving a mission, vision and goals. The application of leadership style can have an influence on operational implementers. Leaders who are able to adjust to the conditions and situations of the organization and can meet the needs of members of the organization will certainly have a positive impact on employees one of which is a sense of belonging to the organization (organizational commitment). The results of this study support research (Yiing and Ahmad, 2009), leadership is related to organizational commitment rather than performance. The implementers of BUMDesa operations have a sense of responsibility towards the community because they carry out the mandate of the community so they have a strong commitment to be able to provide their best performance for the community.

\section{CONCLUSION}

The results showed that the leadership style had a direct influence on the performance of BUMDesa operational operators. The right leadership style in BUMDesa will be able to improve the performance of BUMDesa operational operators, so that it will improve BUMDesa's performance in achieving its goal of prospering the rural community. The results also showed that organizational commitment cannot mediate the relationship between leadership style and performance.

\section{REFERENCES}

[1] Authors, F. (2006) 'Article information 1993-2006', Ship Technology Research, 53(4), pp. 194-200. doi: 10.1179/str.2006.53.4.005.

[2] Baig, S. A. et al. (2019) 'Impact of leadership styles on employees' performance with moderating role of positive psychological capital', Total Quality Management and Business Excellence. Taylor \& Francis, 0(0), pp. 1-21. doi: 10.1080/14783363.2019.1665011.

[3] Eliyana, A., Ma'arif, S. and Muzakki (2019) 'Job satisfaction and organizational commitment effect in the transformational leadership towards employee performance', European Research on Management 
and Business Economics. AEDEM, 25(3), pp. 144150. doi: 10.1016/j.iedeen.2019.05.001.

[4] Irene Muhoho \& Dr.Oloko Margret (2016) 'Influence of Strategic management on the performance of manufacturing firms in Nairobi,Kenya', International Journal of Social sciemces and information Technology, 2(5), pp. 595-616.

[5] Jaramillo, F., Mulki, J. P. and Marshall, G. W. (2005) 'A meta-analysis of the relationship between organizational commitment and salesperson job performance: 25 years of research', Journal of Business Research, 58(6), pp. 705-714. doi: 10.1016/j.jbusres.2003.10.004.

[6] Lapointe, É. and Vandenberghe, C. (2018) 'Examination of the Relationships Between Servant Leadership, Organizational Commitment, and Voice and Antisocial Behaviors', Journal of Business Ethics, 148(1), pp. 99-115. doi: 10.1007/s10551015-3002-9.

[7] Lok, P. and Crawford, J. (2004) 'The effect of organisational culture and leadership style on job satisfaction and organisational commitment: A cross-national comparison', Journal of Management Development, 23(4), pp. 321-338. doi: $10.1108 / 02621710410529785$.

[8] Nawoseing'ollan, D. and Roussel, J. (2017) 'Influence of Leadership Styles on Employees' Performance: A Study of Turkana County, Kenya', International Journal of Business and Social Science, 8(7), pp. 82-98. Available at: www.ijbssnet.com.

[9] Nirushan, K. (2017) 'Impact of Organizational Commitment on Employee Performance Special Reference to Banks in Trincomalee District', SSRN Electronic Journal, (2005). doi: 10.2139/ssrn.3001598.

[10] Suharto, Suyanto and Hendri, N. (2019) 'The impact of organizational commitment on job performance', International Journal of Economics and Business Administration, 7(2), pp. 189-206. doi: 10.35808/ijeba/227.

[11] Trisnaningsih, S. (2007) 'Independensi auditor dan komitmen organisasi sebagai mediasi pengaruh pemahaman', Independensi Auditor Dan Komitmen Organisasi Sebagai Mediasi Pengaruh Pemahaman Good Governance, Gaya Kepemimpinan Dan Budaya Organisasi Terhadap Kinerja Auditor, pp. 1-56. doi: 10.1590/S0104-14282003000200006.

[12] Yiing, L. H. and Ahmad, K. Z. Bin (2009) 'The moderating effects of organizational culture on the relationships between leadership behaviour and organizational commitment and between organizational commitment and job satisfaction and performance', Leadership and Organization Development Journal, 30(1), pp. 53-86. doi: 10.1108/01437730910927106.

[13] Yousef, D. A. (2000) 'Organizational commitment: A mediator of the relationships of leadership behavior with job satisfaction and performance in a nonwestern country', Journal of Managerial Psychology, 15(1), pp. 6-24. doi: 10.1108/02683940010305270. 